\title{
Magnetostratigraphy of the lower Cretaceous strata in Tlayúa Quarry, Tepexi de Rodriguez, State of Puebla, Mexico
}

\author{
Mouloud Benammi ${ }^{1}$, Jesus Alvarado-Ortega ${ }^{2}$, and Jaime Urrutia-Fucugauchi ${ }^{1}$ \\ ${ }^{1}$ Laboratorio de Paleomagnetismo y Geofisica Nuclear, Instituto de Geofísica, UNAM, 04510 México, D.F., Mexico \\ ${ }^{2}$ Departamento de Paleontologia, Instituto de Geologia, UNAM, 04510 México, D.F., Mexico
}

(Received November 23, 2005; Revised March 7, 2006; Accepted May 11, 2006; Online published November 8, 2006)

\begin{abstract}
A stratigraphic sequence of magnetic polarity reversals consisting of nine magnetozones is recognized in Early Cretaceous sedimentary strata in the Tlayúa Quarry of Tepexi de Rodriguez, state of Puebla. Combined with biostratigraphic age assignments using ammonites that apparently belonging to the Albian, the geomagnetic polarity sequence can be correlated with the middle part of chron C34n (C34n.1n-C34n.2n chrons, with an age of 100-105 Myr), the Cretaceous long normal interval. The magnetic properties and characteristic remanence of magnetization are dominated by soft and hard coercivity magnetic minerals. Rock-magnetic properties and a positive reversal test suggest that remanence is primary. The section displays both reverse and normal polarities with mean directions: $D=344.9^{\circ}, I=32.4^{\circ}, k=21$, a95 $=4.2^{\circ}$ and $D=149.4^{\circ}, I=-36.6^{\circ}, k=17$, a95 $=8.7^{\circ}$, respectively. Comparison with the North American apparent polar wander path indicates tectonic stability of the region since the Cretaceous.
\end{abstract}

Key words: Magnetostratigraphy, cretaceous, ammonite biostratigraphy, Tlayúa, Mexico, North America.

\section{Introduction}

The Tlayúa Quarry in Tepexi de Rodríguez, located about $60 \mathrm{~km}$ SE of Puebla City (Fig. 1), is one of the most paleontologically important localities in the New World because of its uniquely rich biota. For the past 20 years, its exceptionally well-preserved fossil content and its taphonomical and paleoecological implications have drawn the attention of many geologists and paleontologists since it represents an important new asset in the field of Mexican Paleontology. The Tlayúa Quarry has yielded more than 6000 specimens to date. Field work, conservation, and the investigation of the fossil materials have been largely carried by the Geological Institute of the Universidad Nacional Autónoma de México (UNAM). The Tlayúa Collection is housed at the Paleontological Museum of the same institution (Colección Nacional de Paleontología), and in only very few exceptions (and these are controlled) are specimens not subject to the custody the Institute's Museum.

Fossil remains are preserved in a honey-colored laminated limestone with red-brown hematite layers which has been used commercially as a flagstone by the Aranguthy family. More that 100 taxa have been found in the quarry, including foraminifera, sponges, annelids, gorgonians, gasteropods, ammonoids (Cantu-Chapa, 1987), belemnoids (Seibertz and Buitron, 1987a, b; Seibertz and Speath, 2002), bivalves, arachnids, crustaceans, insects (Buitron et al., 1993; Gonzalez-Rodriguez and Martinez-Hernandez, 1998; Feldman et al., 1998), echinoids, asteroids, ophiuroids, fishes, reptiles (Reynoso, 1998, 2000; Reynoso and Calli-

Copyright (c) The Society of Geomagnetism and Earth, Planetary and Space Sciences (SGEPSS); The Seismological Society of Japan; The Volcanological Society of Japan; The Geodetic Society of Japan; The Japanese Society for Planetary Sciences; TERRAPUB. son, 2000), algae and terrestrial plants.

Based on ammonite remains (Cantu-Chapa, 1987) and some belemnite fossils, Seibertz and Buitron (1987a, b) proposed an upper Albian age for the Tlayúa Formation. However, based on benthic foraminifera, Kashiyama et al. (2003) proposed a lower Aptian age for the same locality.

In an attempt to resolve this 10 Ma difference between the two proposed biochronological ages, we have carried out a magnetostratigraphic study in the Tlayúa Quarry with the aim of finding correlations with the geomagnetic polarity time scale (GPTS).

\section{Lithostratigraphy and Environment Interpre- tation}

The Tlayúa quarry first appeared in the literature as a new fossil locality some 20 years ago (Applegate and EspinosaArrubarrena, 1982; Appelgate et al., 1984). The Tepexi de Rodriguez area lies within the region of Paleozoic metamorphic rocks of the Acatlan complex (Applegate et al., 1984). The basic aspects of the geology of the Tlayúa Quarry were reported by Pantoja-Alor (1992) who proposed the name Tlayúa Formation based on the presence of Albian carbonates that are exposed in the Tlayúa Quarry. He subdivided these into three members (Fig. 1(d)): the Lower, Middle, and Upper Members. The Lower Member consists of at least $50 \mathrm{~m}$ of bioturbated, gently dipping bluish gray micritic limestones that contain the rudistid Toucasia polygyra and the bivalve Chondrodonta in its lowest part. It also contains numerous beds with miliolids and is capped by limestone that contains undetermined molluscan fauna of very small bivalves and gastropods (Espinosa-Arrubarrena and Applegate, 1996). The Middle Member is $25 \mathrm{~m}$ thick and consists of the quarry's fine-grained laminated micritic 


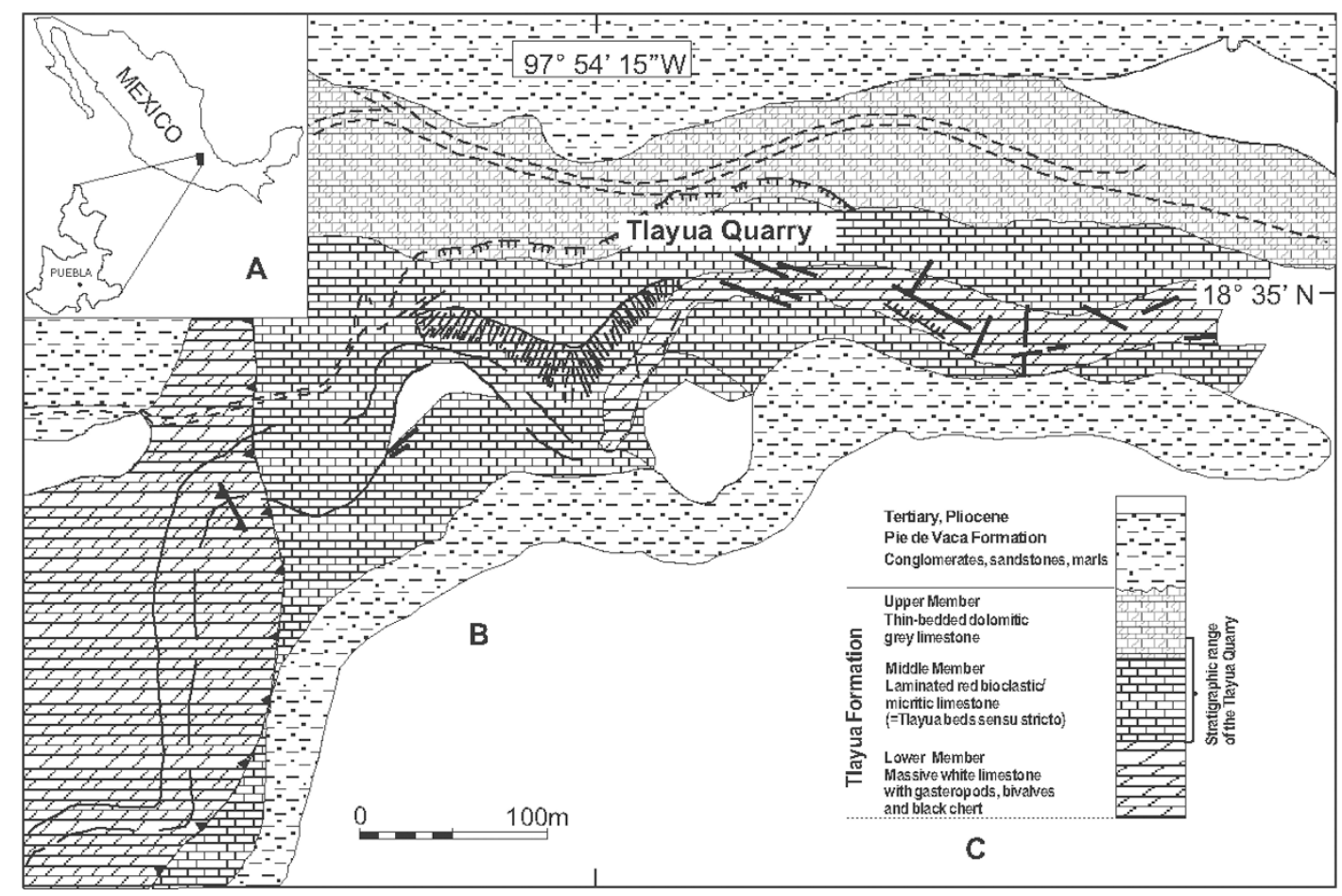

Fig. 1. (A) Location of the study area in central Mexico. (B) geologic sketch of the immediate surrounding of the Tlayúa quarry in the upper Barranca Tlayúa (redrawn from Pantoja-Alor, 1992). (C) Generalized lithostratigraphic section of the Barranca Tlayúa.

limestone. It is the most important segment, due to the numerous and diverse fossil assemblage found in it. The bedding planes contain thin red hematitic layers that bear a large array of well-preserved fossils. The Upper Member of the Tlayúa Formation consists of a sequence of gray dolomites. In some areas, the Tlayúa Formation is covered by continental sediments of Pie de Vaca Formation and Agua de Luna Formation. Its base is not exposed, however the oldest rocks that crop out in the Tepexi de Rodriguez area are Paleozoic metamorphic rocks of the Acatlan complex.

Several attempts have been made to understand the paleoenvironment and post-depositional conditions that produced this remarkable preservation of fossils at Tlayúa. The Tlayúa deposit has been interpreted to be a restricted shallow lagoon bordered to the east and north by large coral reefs (Applegate, 1987, 1992; Espinosa-Arrubarrena and Applegate, 1996). Another barrier has been proposed to exist landwards, separating the "normal" marine lagoon from the back lagoon area in which the Tlayúa sediments were deposited. In this paleoenvironmental model, the exceptional preservation found at Tlayúa was promoted by restricted circulation, which resulted in an anaerobic and/or hypersaline environment that corresponds to a toxic bottom almost barren of infaunal species. According to Applegate (1992), there were periods in the back lagoon during which the site supported a rich planktic community that produced large quantities of calcareaous ooze which, in turn, caused a rapid burial. The presence of diagnostic terrestrial and freshwater organisms, including arachnids, insects, lizards, chelonians and land plants, along with typical marine biotas suggests that the Tlayúa lagoon had a periodic fresh water inflow in addition to the strong, marine la- goonal and reefal influence (Feldmann et al., 1998). The allochthonous nature of the deposit indicates that some organisms were transported into the back lagoon when the barrier was breached, probably during periods of heavy rains and hurricanes, or maybe during in high tide cycles (Applegate, 1992). Kashiyama et al. (2003) recently proposed an alternative paleoenvironmental interpretation and rejected the idea that Tlayúa represents a lagoon. Based on petrology and spectral analyses, they proposed a fully marine depositional basin that never underwent subaerial exposure.

\section{Sampling}

The section was measured in the quarry where an unusually fresh face was exposed by the quarrying operation. Samples were collected from 31 horizons (Fig. 2(A)) through the upper part of the Lower Member and all of the Middle Member of the Tlayúa Formation. The estimated stratigraphic gap between the Lower and the Middle Member is approximately $10 \mathrm{~m}$ based on a bedding dip of $5^{\circ}$. The paleomagnetic sampling was carried out along $35 \mathrm{~m}$ of the section using a water-cooled rock drill and magnetic compass orientation. Different stratigraphic levels were sampled, and three samples or more per level were collected, amounting to a total of 95 oriented samples. All samples were cut into standard cores of 2.5-cm-long cylinders.

\section{Magnetic Measurements}

Low-field magnetic susceptibility $(k)$ was measured using a Bartington MS2B susceptibility meter. Measurements of natural remanent magnetization (NRM) were made using a JR6 (noise level: approx. $0.002 \mathrm{~mA} / \mathrm{m}$ ). Multiple specimens from the core-sample at each horizon were subjected to stepwise thermal demagnetization using a Schonstedt 
A

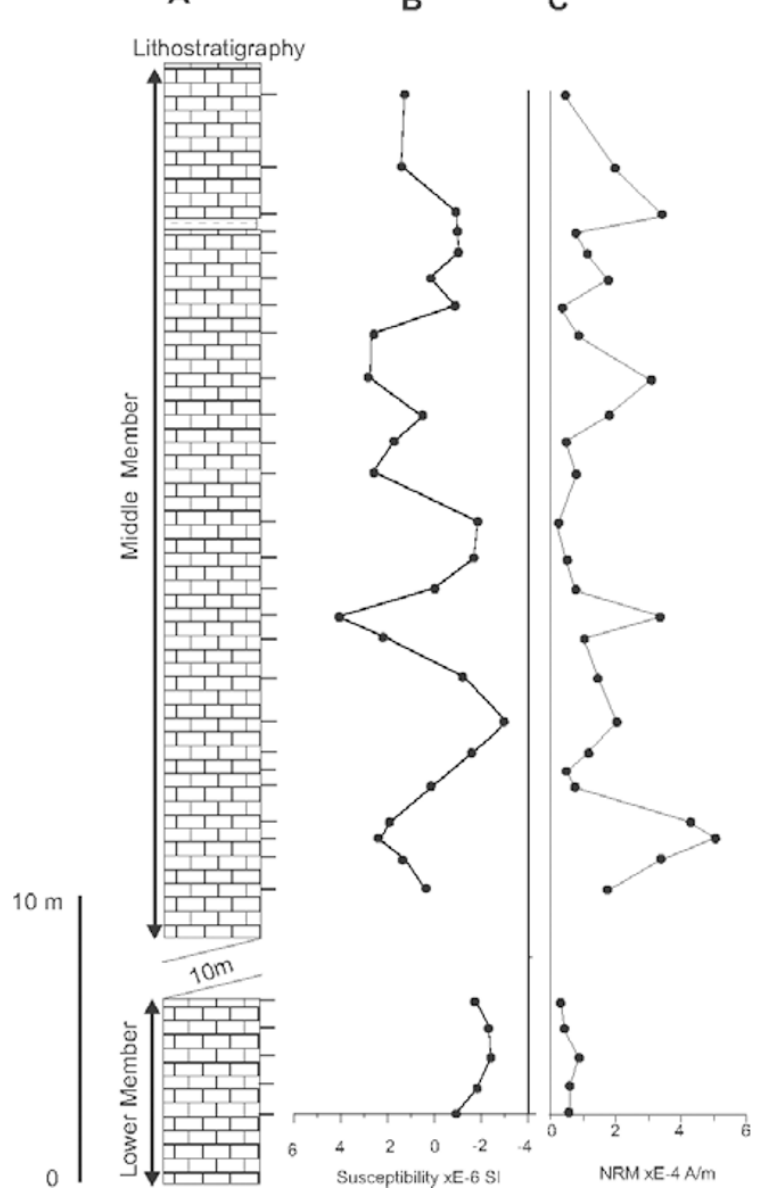

Fig. 2. (A) Lithology and stratigraphic position of sampling sites of the Tlayúa Formation. Line at the right of the column indicates the position of paleomagnetic sites. (B, C) Susceptibility and NRM intensities plotted against lithostratigraphic position.

thermal demagnetizer at room temperature up to $620^{\circ} \mathrm{C}$. The specimen demagnetization results were analyzed using principle component analysis (Kirschvink, 1980). The magnetic mineralogy for some samples was studied using stepwise acquisition and thermal demagnetization of isothermal remanent magnetization (IRM). Remanence measurements were made with both a JR5 and JR6 spinner magnetometer, and thermal demagnetization was achieved using the same thermal demagnetizer. Susceptibility was measured after each step to monitor the thermally-induced mineralogical alteration.

\section{Results}

\subsection{Magnetic properties}

To examine magnetic mineralogy, stepwise IRM acquisition experiments were performed using a pulse magnetizer. The acquired IRM plots (Fig. 3(A)) show an initial increase in intensity due to low coercivity minerals (magnetite), but also a consistent increase up to $3 \mathrm{~T}$ that is indicative of a percentage of high coercivity minerals such as hematite or goethite.

Three-axis IRM tests (Lowrie, 1990) were performed using field strengths of 1.0, 0.5, and $0.1 \mathrm{~T}$. These values were chosen to so as to be able to separate the coercivity fractions of hematite and goethite from magnetite and other lesser coercivity components. The tests revealed three groups of behaviors.

Group 1: The lesser coercivity fraction dominates the signal (Fig. 3(B)). The inflexion of the curve at about $200^{\circ} \mathrm{C}$ indicates the probable presence of titano-magnetite. Upon thermal demagnetization, the low coercivity component shows an unblocking temperature of $650^{\circ} \mathrm{C}$, signifying the probable presence of hematite. Higher and medium coercivity components contribute minimally to the overall magnetization of the specimen, and their unblocking temperature is around $650^{\circ} \mathrm{C}$, indicating the presence of hematite. The susceptibility curve is constant until the final demagnetization. This sample is dominated by hematite and titanomagnetite.

Group 2: The IRM acquisition curve shows that this sample contains minerals with strong coercivity. The dominant IRM component is the highest coercivity fraction (Fig. 3(C)). Thermal demagnetization shows that the $\mathrm{Z}$ component decreases strongly at $100^{\circ} \mathrm{C}$, indicating the presence of goethite. Between 100 and $500^{\circ} \mathrm{C}$, the curve decreases gradually without inflection, indicating the presence of magnetite. After $100^{\circ} \mathrm{C}$, the $\mathrm{Y}$ component decreases gradually, which is indicative of goethite, and is completely demagnetized at $580^{\circ} \mathrm{C}$, suggesting the presence of magnetite. While the $\mathrm{X}$ component demagnetized at $580^{\circ} \mathrm{C}$, also indicating the presence of magnetite, it is the same as that of the Y component. This sample is dominated by goethite and magnetite.

Group 3: Low coercivity dominates the magnetization of the sample. The X, Y, and Z components decrease gradually without any inflection until their complete demagnetization towards $650^{\circ} \mathrm{C}$. These three components are dominated by hematite. The susceptibility curve (Fig. 3(E)) is constant until $600^{\circ} \mathrm{C}$ where it shows an increase. This increase is probably due to the transformation of paramagnetic or ferromagnetic minerals. The mineralogy of this sample is characterized by the hematite.

\subsection{Specimen palaeomagnetic behavior}

The intensity of the NRM and susceptibility is often low (Fig. 2(B)), with the most frequent intensities of magnetization ranging between 0.1 and $9.310^{-4} \mathrm{~A} / \mathrm{m}$ and the susceptibility ranging between -3.6 and 4.1 E-6 SI (Fig. 2(C)). In order to reveal the original NRM, we demagnetized at least 98 specimens collected from the 31 sampled horizons. Most specimens were demagnetized thermally in a non-magnetic furnace. The Zijderveld (1967) demagnetization diagrams reveal the existence of several components (Fig. 4). The first component is generally a small randomly oriented component that can be removed at $100^{\circ} \mathrm{C}$. The mostly random orientation and the relatively soft character of this component lead to the conclusion that it is laboratory-induced viscous magnetization. The second component is a relatively large component, representing in some case about $60 \%$ of the original intensity of the specimens (only in tow samples, Fig. 4(A)). From the thermal decay curves it can be seen that most of this component is removed at $200-250^{\circ} \mathrm{C}$. With the exception of the sample in Fig. 4(A), this component has a normal polarity with a present-day direction in most samples. The third component is revealed at higher 

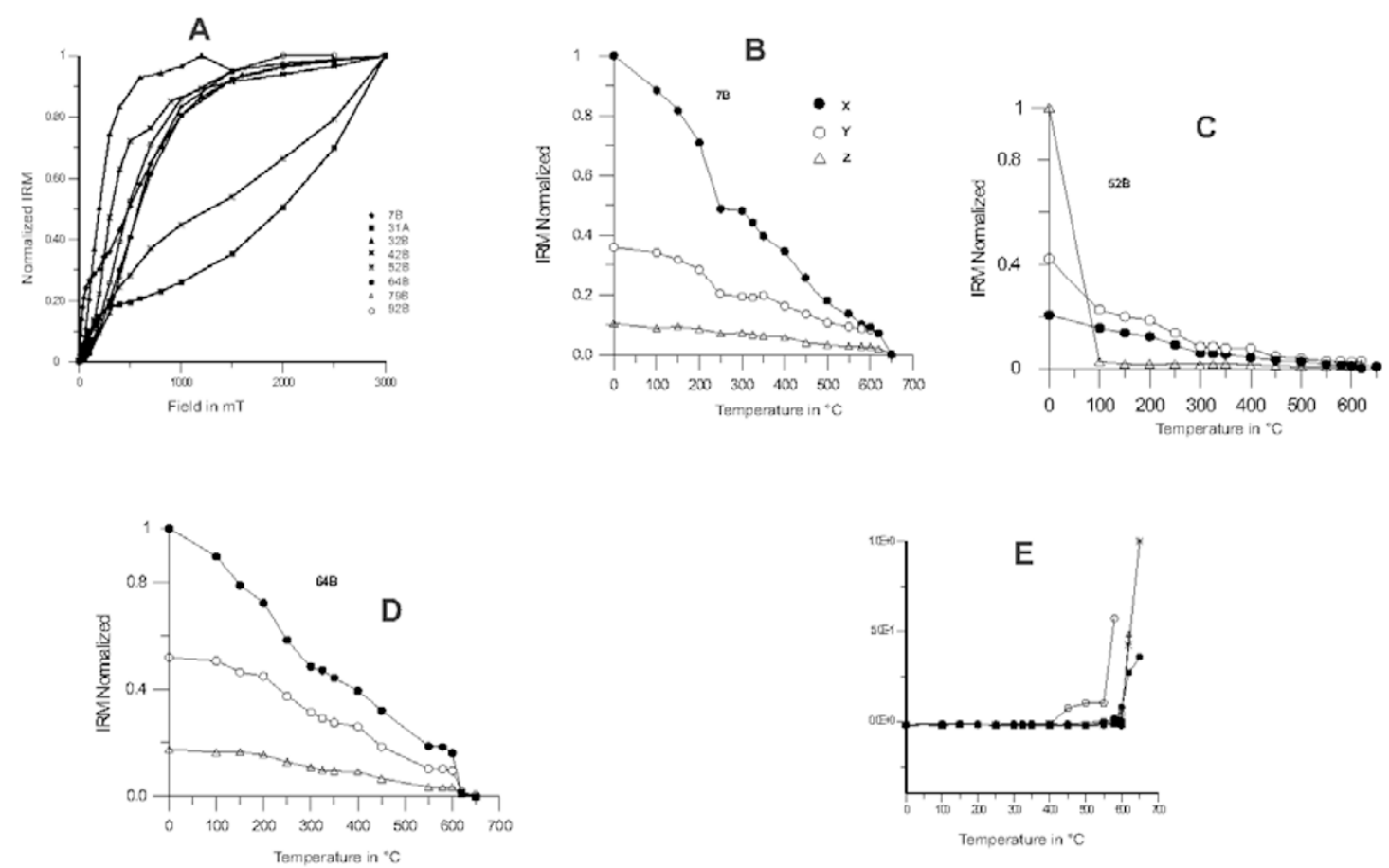

Fig. 3. (A) Examples of IRM acquisition (normalized values) of some samples of the Tlayua section. (B, C, D) Stepwise thermal demagnetization of the normalized IRM components (X, Y and Z). Solid circles indicate the soft component $0.1 \mathrm{~T}$ field; open circles indicate the medium component, $0.5 \mathrm{~T}$ field; triangles indicate the hard component, $1 \mathrm{~T}$. (E) Low-field susceptibility during thermal demagnetization, the increase in susceptibility indicates the mineralogical transformation.

Table 1. Summary of paleomagnetic data ${ }^{\mathrm{a}}$.

\begin{tabular}{|c|c|c|c|c|c|c|c|}
\hline \multirow[t]{2}{*}{ Site } & \multirow[t]{2}{*}{ Polarity } & \multirow[t]{2}{*}{$\mathrm{n} / \mathrm{N}$} & \multicolumn{3}{|c|}{ chRM mean } & \multirow[b]{2}{*}{$\mathrm{kb}$} & \multirow{2}{*}{$\begin{array}{l}\text { VGP } \\
\text { lat. }\end{array}$} \\
\hline & & & direction $D$ & $I$ & $\alpha 95$ & & \\
\hline 1 & $\mathrm{~N}$ & $3 / 3$ & 4.3 & 34.2 & 15.3 & 66 & 85.9 \\
\hline 2 & $\mathrm{~N}$ & $3 / 3$ & 351.6 & 32.4 & 12.3 & 101 & 82.0 \\
\hline 3 & $\mathrm{~N}$ & $3 / 3$ & 352.9 & 36.6 & 17.1 & 53 & 74.0 \\
\hline 4 & $\mathrm{~N}$ & $2 / 3$ & 318.3 & 37.9 & - & - & 76.0 \\
\hline 5 & $\mathrm{~N}$ & $3 / 3$ & 357.3 & 38.7 & 18.5 & 46 & 85.8 \\
\hline 6 & $\mathrm{~N}$ & $2 / 3$ & 343.4 & 33.9 & 33 & 3 & 64.5 \\
\hline 7 & $\mathrm{~N}$ & $4 / 4$ & 339.3 & 30.8 & 4.2 & 487 & 70.1 \\
\hline 8 & $\mathrm{~N}$ & $4 / 4$ & 342.0 & 26.2 & 3.9 & 464 & 72.0 \\
\hline 9 & $\mathrm{~N}$ & $3 / 3$ & 338.1 & 26.7 & 3.7 & 1113 & 68.5 \\
\hline 10 & $\mathrm{~N}$ & $3 / 3$ & 342.2 & 31.5 & 19.4 & 41 & 72.9 \\
\hline 11 & $\mathrm{~N}$ & $3 / 3$ & 347.0 & 19.2 & 18.8 & 44 & 74.7 \\
\hline 12 & $\mathrm{~N}$ & $2 / 2$ & 332.1 & 32.8 & - & - & 63.5 \\
\hline 13 & $\mathrm{~N}$ & $3 / 3$ & 332.9 & 36.3 & 17.8 & 64.3 & \\
\hline 14 & $\mathrm{~N}$ & $3 / 3$ & 343.4 & 25.3 & 22.6 & 31 & 73.2 \\
\hline 15 & $\mathrm{R}$ & $1 / 3$ & 158.0 & -54.1 & - & - & -62.3 \\
\hline 16 & $\mathrm{~N}$ & $3 / 3$ & 338.6 & 38.5 & 6.5 & 362 & 69.6 \\
\hline 17 & $\mathrm{~N}$ & $2 / 3$ & 348.2 & 54.3 & - & - & 70.6 \\
\hline 18 & $\mathrm{R}$ & $3 / 3$ & 173.6 & -27.7 & 23.5 & 29 & -82.7 \\
\hline 19 & $\mathrm{R}$ & $2 / 3$ & 160.6 & -40.5 & - & - & -58.4 \\
\hline 20 & $\mathrm{R}$ & $2 / 3$ & 157.5 & -62.1 & - & - & -67.0 \\
\hline 21 & $\mathrm{R}$ & $2 / 3$ & 148.7 & -28.3 & - & - & -59.8 \\
\hline 22 & $\mathrm{R}$ & $2 / 3$ & 140.2 & -30.3 & - & - & -61.5 \\
\hline 23 & $\mathrm{~N}$ & $3 / 3$ & 335.2 & 32.3 & 11.2 & 123 & 66.4 \\
\hline 24 & $\mathrm{R}$ & $2 / 3$ & 163.9 & -30.8 & - & - & -74.5 \\
\hline 25 & $\mathrm{R}$ & $2 / 3$ & 194.2 & -35.2 & - & - & -76.5 \\
\hline 26 & $\mathrm{~N}$ & $3 / 3$ & 342.0 & 31.3 & 30.6 & 17 & 72.8 \\
\hline 27 & $\mathrm{R}$ & $3 / 3$ & 143.9 & -35.0 & 12.5 & 99 & -55.9 \\
\hline 28 & $\mathrm{R}$ & $3 / 3$ & 143.4 & -43.4 & 42.1 & 10 & -55.5 \\
\hline 29 & $\mathrm{~N}$ & $3 / 3$ & 339.9 & 44.0 & 17.9 & 49 & 70.0 \\
\hline 30 & $\mathrm{~N}$ & $3 / 3$ & 353.2 & 26.0 & 29.3 & 19 & 82 \\
\hline 31 & M & $2 / 3$ & 32.8 & 344 & - & - & 74.7 \\
\hline
\end{tabular}

${ }^{\mathrm{a}} \mathrm{ChRM}$, Characteristic remanent magnetization; $D, I$, mean direction; VGP, virtual geomagnetic pole $(\mathrm{Lt})$.

${ }^{\mathrm{b}} k$ and $\alpha 95$ are the Fisher's parameters (Fisher, 1953). temperatures and has one of the two characteristic directions, either with a positive inclination and a normal declination (Fig. 4(A, B, E-G)) or a negative inclination and southward declination (Fig. 4(D, H, I)). This third component is the characteristic remanent magnetization. Among all the samples taken, the remanent intensity of some specimens drops sharply at $100^{\circ} \mathrm{C}$ below or close to the noise level of our JR6 magnetometer; therefore, they did not give reliable results (Fig. 4(C)). The thermally demagnetized specimens showed a stable behavior during demagnetization (Fig. 4(D)). The measured remanence directions are stable, but in some samples they become scattered at higher temperatures $\left(>500^{\circ} \mathrm{C}\right)$, which may be the result of chemical and/or mineralogical alterations during heating. Furthermore, these demagnetizations show that samples have at least two distinct reverse magnetic components.

\subsection{Paleomagnetic directions}

We obtained reliable characteristic remanent magnetization (ChRM) directions from the Tlayúa Formation (Table 1). Following tilt correction, ChRM directions were combined using Fisher statistics (1958) to calculate mean directions $D=344.9^{\circ}, I=32.4^{\circ}, k=21, \alpha 95=4.2^{\circ}$ and $D=149.4^{\circ}, I=-36.6^{\circ}, k=17, \alpha 95=8.7^{\circ}$ ) (Fig. $4(\mathrm{~J})$ ). Our section provided reverse and normal polarities, respectively, thereby supporting a primary origin of the ChRM following the positive reversal test (McFadden and McElhinny, 1990). However, the fold test was not possible as bedding is uniform at the local section. The two directions are not antipodal, probably due to the strong overprint of the present-day field which may not have been removed completely. To limit the biasing effect due to the present-day overprint, we referred all directions to the common (lower) 

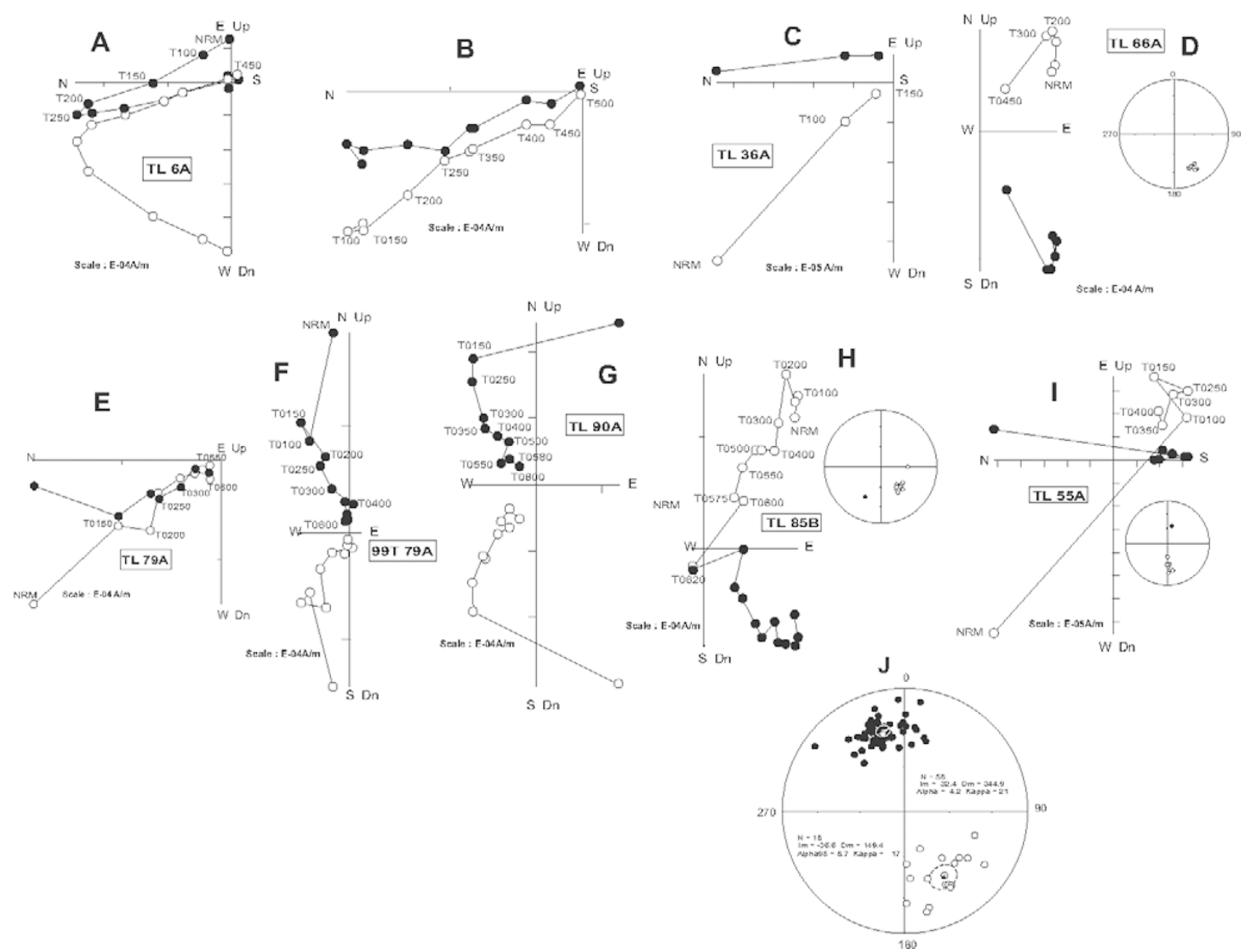

Fig. 4. (A-I) Examples of orthogonal vector diagrams of progressive thermal demagnetizations. Solid and open circles are projections on the horizontal and east-west vertical planes, respectively, in coordinates following the correction for bedding tilt. (A, B, E-G) Normal polarity characteristic directions isolated at high unblocking temperatures. (D, H, I) Reversal polarity characteristic directions; the stereographic projection of the same sample is shown at the right of the orthogonal diagram. (J) Equal-area projections of magnetization directions of 21 horizons of normal and ten of reversed, after correction for bedding tilt. Solid circles are plotted on the lower hemisphere and open circles on the upper hemisphere. Overall mean directions and their $95 \%$ error limits are given in boxes. The star shows the present dipole field direction.

hemisphere and calculated an overall mean of $D=341^{\circ}$; $I=35.4^{\circ} ; k=35 ; \alpha 95=4.3^{\circ}$. We compared our directions with the reference directions for stable North America derived from the apparent polar wander (APW) path of Besse and Courtillot (2003). For the Tlayúa Formation, we referred to the direction at $110 \mathrm{Ma}$ and found that the Tlayúa direction is close to that expected from stable North America $\left(D=342.4^{\circ}, I=40.8^{\circ}\right)$, with a slightly lower inclination. The inclination value is lower than expected at the site latitude for the middle Cretaceous magnetic field. This difference may be interpreted as an inclination shallowing due to the depositional geometry. It is typical of detrital remanence (DRM). Paleomagnetic data therefore suggest no significant relative movements of the Tlayúa Formation relative to stable North America during the middle Cretaceous. The paleomagnetic data obtained from a nearby limestone succession of the Morelos Formation suggests tectonic stability between southern Mexico and North America (Urrutia-Fucugauchi, 1988).

\subsection{Polarity zones and correlation}

The ChRM directions were converted into virtual geomagnetic pole (VGP) latitude (Opdyke and Channell, 1996) with respect to the combined mean direction pole at $18.5^{\circ} \mathrm{N}$, $97.9^{\circ} \mathrm{W}$ site coordinate. Based on VGP latitude, each level was assigned a polarity (Table 1, Fig. 5(B), (C)). The data yielded the following results. The lower five sites belonging to the lower member representing $4 \mathrm{~m}$ have normal polarity $\mathrm{N} 1$. Above these, and after a gap of about $10 \mathrm{~m}$, the section continues with $8.6 \mathrm{~m}$ of normal polarity, followed by 15 $\mathrm{m}$ of reversed polarity. This reverse polarity is punctuated by three relatively short normal polarities N2-N4. The last normal polarity N5 is represented by three sites, each $5 \mathrm{~m}$ thick. The question remains as to which part of the reversal time scale this series of reversals belongs. The only independent means of correlation available at the present time is the biochronological age.

\section{Biostratigraphy}

Since the discovery of the Tlayúa quarry, paleontologists have attempted to date it. Kashiyama et al. (2003) recognized the following benthic foraminifera: Spiroloculina cretacea, Trochamminoides coronus, Derventina filipescui, Sabodia minuta, Rumanoloculina robusta, Valvulineria sp., Earlandia? conrodi, prob. Praechrysalidina infracretacea, 
A

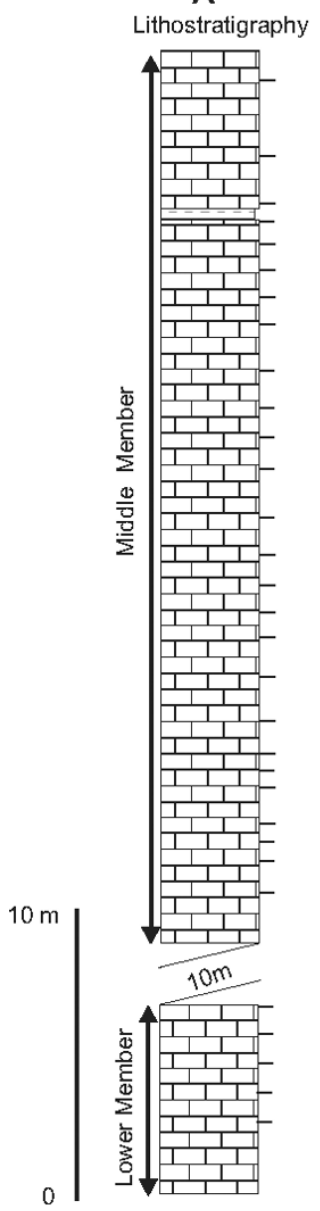

B

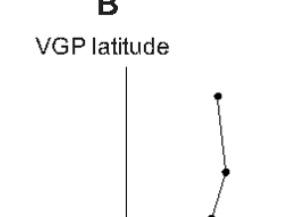

C

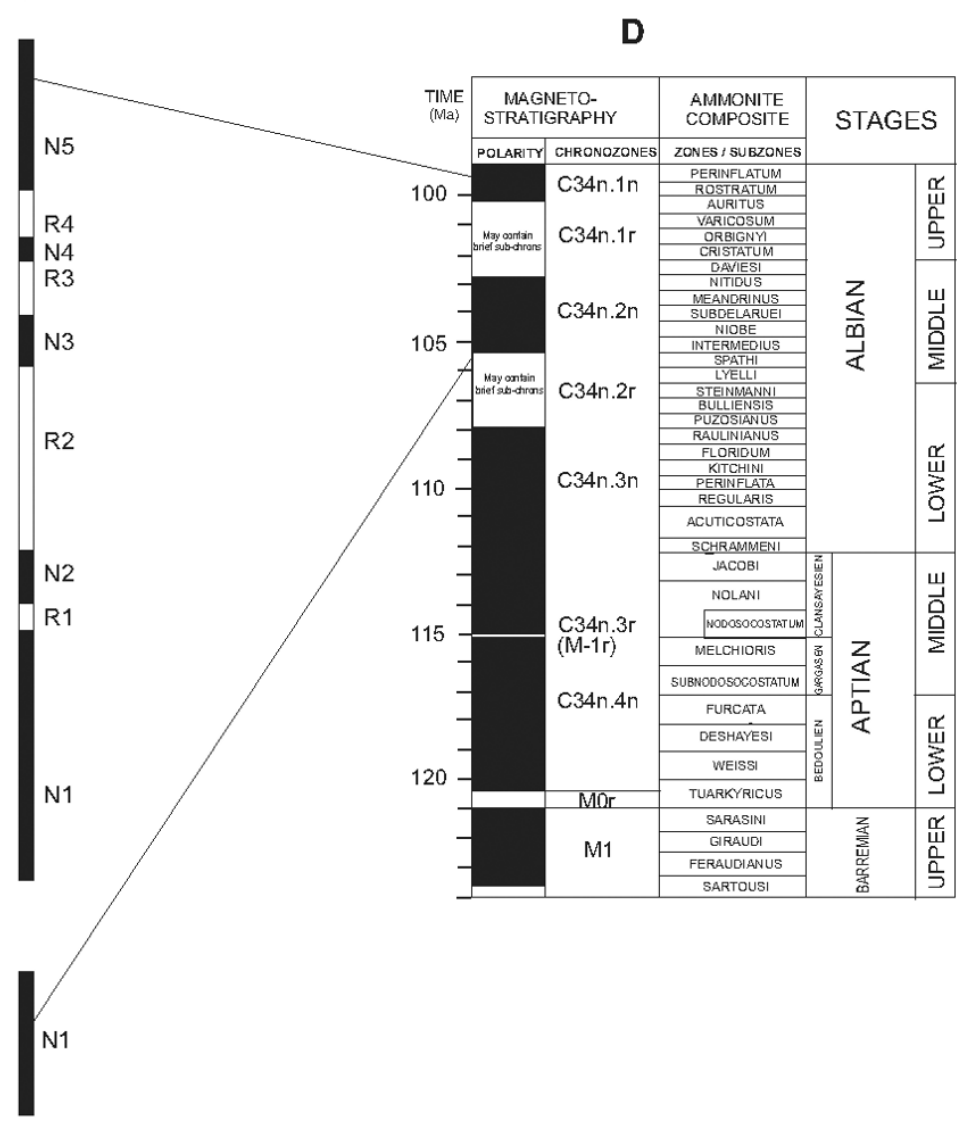

Fig. 5. Lithology and magnetostratigraphy of the Tlayúa Formation, and correlation of the polarity zones (C) to the geomagnetic polarity time scale (GPTS). (A) Lithology as in Fig. 2. (B) Latitude of virtual geomagnetic pole (VGP) of ChRM as a function of stratigraphical level. (C) Polarity column, black denotes normal polarity and white denotes reversed polarity zones. The boundaries between the magnetozones are placed at a midpoint between adjacent horizons of opposite magnetic polarity. Lines indicate correlation of magnetozones to polarity chrons for the Lower Cretaceous. (D) Polarity time scale after Gradstein et al. (1995, 2004).

and Nautiloculina sp. These authors proposed a lower Aptian age for this association, which is typical of lower Aptian inner shelf sediments in the Apennines as well as in the West Alps-Vercors, and Chartreuse regions. However, some species have a large stratigraphic range that exceeds the Aptian. For example, Praechrysalidina infracretacea is known from the lower Aptian to the end of the Albian, Sabudia minuta stretch as far as the middle Albian, while spiroloculina cretacea is known only from the lower Cenomanian (Chiocchini et al., 1984). Based on these observations, the age of this association could be younger than the age proposed by Kashiyama et al. (2003).

In North America, a high-resolution ammonite zonation is available for the Cenomanian through to the lower Maastrichtian interval (Cobban et al., 1994). The lower Cretaceous is subdivided into 66 ammonite zones and subzones (Gradstein et al., 1995), from the upper Valanginian to the Albian.

Cantu-Chapa (1987) recognized the ammonite genera Hysteroceras, Mortoniceras and cf. Anisoceras. This material represents a typical late Albian ammonite fauna of the European ammonite zone. The ammonite assemblage shows a similarity to the Mortoniceras inflatum zone of the proposed stratotype for the Albian-Cenomanian boundary at Mont Risou, south-east France (Table 2; Gale et al., 1996). Therefore we consider it more reliable to assign a Late Albian age to the fossilifereous locality of the Tlayúa quarry based on ammonite stratigraphy.

\section{Correlation and conclusion}

A long period of uniformly normal polarity in the Cretaceous was first detected by Helsley and Steib (1969), who suspected that it corresponds to vast stretches of relatively low amplitude behavior in the sea-floor magnetic anomaly profiles (Raff, 1966; Heirtzler et al., 1968) (known informally as the Cretaceous "quiet zone"). Since these first studies, paleomagnetists have continued to explore what is now called the Cretaceous Normal Superchron (CNS), an interval of prolonged normal polarity from 118 to 84 Ma. Most of the Cretaceous magnetostratigraphic studies have been carried out on pelagic limestones in the Mediterranean region (Opdyke and Channell, 1996). However, paleomagnetists have continued to explore the CNS by conducting land-based studies on samples from the pelagic limestones of northern and central Italy (Vendenberg et al., 1978; Tarduno et al., 1992; Cronin et al., 2001). Paleomagnetic data 
Table 2. Ammonite zonal and subzonal scheme for the Late Albian-European province (after Wiedmann and Owen, 2001).

\begin{tabular}{ll}
\hline Late Albian zone & Subzone \\
\hline Stolczkaia (Stoliczkaia) dispar & Arrhaphoceras (Praeschloenbachia) briacensi \\
& Mortoniceras (Durnovarites) perinflatum \\
& Mortoniceras (Mortoniceras) rostratum \\
& Callihoplites auritus (early part and later interval with \\
& Mortoniceras (Cantabrigites) minor) \\
Mortoniceras (Mortoniceras) inflatum & Hysteroceras varicosum \\
& Hysteroceras orbignyi \\
& Diploceras cristatum later part of the subzone only \\
\hline
\end{tabular}

from sediment cores recovered from the Deep Sea Drilling Project (DSDP) Holes 369, 386, and 364, were interpreted as evidence for several brief intervals of reversed polarity in the Albian (Keating and Helsley, 1978a, b, 1979). UrrutiaFucugauchi (1988) pointed out the possible existence of a reversed polarity interval within the CNS in the Cretaceous Morelos Formation. Seven reversed polarity zones have been observed by Tarduno et al. (1992) in the middle Albian interval at the Contessa section (Umbria, Central Italy).

The Gradstein et al. (2004) Geomagnetic Time Scale for the CNS (C34) appears as three chrons with reverse polarity zone. The oldest one of these is designated M-1r; the others have not yet been designated. We propose to give a nomenclature to the different chrons following the international nomenclature (Anonymous, 1979). This nomenclature would facilitate discussion on the correlation of our magnetostratigraphic section to the GPTS. The proposed nomenclature is given in Fig. 5(D).

In the late Albian, the subzones of Hysteroceras orbignyi and $H$. varicosum have been recognized as being are capable of being geographically very widespread outside of the Europe province (Wiedmann and Owen, 2001). According to our polarity chron interpretation (Fig. 5), Mortoniceras and Hysteroceras occur at the polarity chron C34n.1r (magnetozones R1-R4 are correlated with chron C34n.1r); in fact, Gradstein et al. (1995) noted the presence of a short interval of normal polarity in this chron. This interpretation appears to be consistent with a proposal by Gradstein et al. (1995), who placed the Mortoniceras inflatum Zone of the European province in the late Albian. This correlation gives a sedimentation rate of about $0.6 \mathrm{~cm} / \mathrm{ka}$.

Only two intervals of reverse magnetic polarity are related to the Aptian stage. The older is chron CMOr, which represents the last anomaly of the M-sequence; the younger is a short, reverse polarity excursion, or subchron, within the CNS, designated ISEA, after the site of reversed polarity discovered by Vandenberg et al. (1978). The reverse polarity event of CMOr took place during the very beginning of the Aptian and lasted some $200 \mathrm{ka}$, and the age of the ISEA (M-1r) event is older than $115 \mathrm{Ma}$ (Gvirtzman et al., 1996), but the duration of the event is estimated to be less than $100 \mathrm{ka}$ (Tarduno, 1990).

If the lower Aptian age proposed by Kashiyama et al. (2003) is correct, the only possible correlation is with one of the reversed chrons. This correlation can be rejected because these chrons are of short duration and contain no normal polarities while those of our magnetostratigraphic results did contain normal polarities.

This is the first report of reversed polarity being detected in the mudstone sequence of Tepexi de Rodriguez. The reverse polarity and the biochronologic age were also determined in the same stratigraphic section. Furthermore, the correlation of the Tlayúa Formation with late Albian time, rather than with the early Aptian, is based on ammonite chronology. This is a new approach, based on ammonite biostratigraphy, compared to the micropalaeontological criteria used for the correlations.

Based on our paleomagnetic study, we conclude that the age of the Tlayúa Formation within the Cretaceous Normal Polarity Superchron is 100-105 Ma. Our results do not support the Aptian age suggested recently by Kashiyama et al. (2003). This investigation supports the presence of reversal polarities with the Albian stage, as already suggested by other authors.

Acknowledgments. The authors are grateful the Aranguthy family. This work was supported by Research Projects B126, 45145-F and DAGPA IN-116201-3 of the Instituto de Geofísica, Universidad Nacional Autónoma de México. We dedicate this work to Shelton P. Applegate, the founder of Tlayúa Paleoichtyology.

\section{References}

Anonymous, Magnetostratigraphic polarity units-A supplementary chapter of the ISSC international stratigraphic guide, Geology, 7, 578-583, 1979.

Applegate, S. P., A preliminary study of the Tlayua Quarry near Tepexi de Rodríguez, Puebla, Rev. Soc. Mex. Paleontol., 1, 40-54, 1987.

Applegate, S. P., A new genus and species of pycnodont from the Cretaceous (Albian of central Mexico, Tepexi de Rodríguez, Puebla), Universidad Nacional Autonoma de México, Inst. Geol. Rev., 10, 164-178, 1992.

Applegate, S. P. and L. Espinosa-Arrubarrena, Lithostratigraphic limestone like deposits in Tepexi de Rodriguez, Puebla. Field guide for the excursion, edited by Espinosa Arrubarrena, Luis, Universidad Nacional Autonoma de Mexico, Inst. Geol. Rev., 7, 200-205, 1982.

Applegate, S. P., L. Espinosa-Arrubarrena, and P. Lopez-Neri, Las calizas litograficas de la cantera Tlayua en tepexi de Rodriguez, Puebla, Mexico, Sociedad Geologica Mexicana, Convencion Geologica Nacional, 7, Mexico D.F., Libreto-guia de la excursion a Tepexi de Rodriguez, Estado de Puebla, 1-83, 1984.

Applegate, S. P., K. Gonzalez-Rodríguez, and J. Alvarado-Ortega, Fish fauna of the Tlayua quarries, Guide book for field trip, 60th Annu. Meet. Society of Vertebrate Paleontology, 97-105, 2000. 
Besse, J. and V. Courtillot, Apparent and true polar wander and the geometry of the geomagnetic field over the last $200 \mathrm{Myr}$. Correction, $J$. Geophys. Res., 108(B11), 2300, doi:10.1029/2003JB002684, 2003.

Buitron-Sanchez, B. E., Velasco de P. Leon, and J. Pantoja-Alor, Un diptero tipulido del Albiano de Tepexi de Rodriguez, Puebla, Mem. IV Cong. Nac. Paleontol. Resum., 4, 22-23, 1993.

Cantu-Chapa, A., Las amonitas del Albiano superior de Tepexi de Rodríguez, Puebla, Rev. Soc. Mex. Paleontol., 1, 159-160, 1987.

Chiocchini, M., A. Mancinelli, and A. Romano, Stratigraphic distribution of benthic foraminifera in the Aptian, Albian and Cenomanian carbonate sequences of the Aurunci and Ausoni mountains, southern Lazio, Italy, BENTHOS'83/2eme Symposium international sur les Foraminifères benthiques Bulletin des Centres de Recherches Exploration-Production Elf-Aquitaine, Mémoire, 6, 167-181, 1984.

Cobban, W. A., E. A. Merewether, T. D. Fouch, and J. D. Orbadovich, Some Cretaceous shorelines in the Western Interior of the United States, in Mesozoic Systems of Rocky Moutain Region, USA, edited by M. V. Caputo, J. A. Peterson, and K. J. Franczyk, pp. 393-425, 1994.

Cronin, M. , L. Tauxe, C. Constable, P. Selkin, and T. Pick, Noise in the quiet zone, Earth Planet. Sci. Lett., 190, 13-30, 2001.

Espinosa-Arrubarrena, L. and S. P. Applegate, A paleoecological model of the vertebrate bearing beds in the Tlayua quarries, near Tepexi de Rodríguez, Puebla, Mexico, in Mesozoic Fishes, Systematic and Paleoecology, edited by G. Arratia and G. Viohl, Verlag Dr. Friedrich Pfeil, Munchen, Germany, pp. 539-550, 1996.

Feldmann, R. M., F. J. Vega, S. P. Applegate, and G. Bishop, Early Cretaceous arthropods from the Tlayua Formation at Tepexi de Rodríguez, Puebla, México, J. Paleontol., 72, 79-90, 1998.

Fisher, R. A., Dispersion on a sphere, Proc. Roy. Soc. Lond., 217, 295-305, 1953.

Gale, A. S., W. J. Kennedy, J. A. Burnett, M. Caron, and B. E. Kidd, The Late Albian to Early Cenomanian succession at the Mont Risou near Rosans (Drome, SE France): an integrated study (ammonites, inoceramids, planktonic foraminifera, nannofossils, oxygen and carbon isotopes), Cretaceous Res., 17, 515-606, 1996.

Gonzalez-Rodriguez, K. A. and E. Martinez-Hernandez, Habitos alimenticios de los macrosemidos (Osteichthyes-Neopterygii-Halecostomi) de la Formacion Tlayua (Albiano) de Tepexi de Rodriguez, Puebla, Soc. Mex. Paleontol., 6, 26-27, 1998.

Gradstein, F. M., F. P. Agterberg, J. C. Ogg, J. Hardenbol, P. Van Veen, J. Thierry, and Z. Huang, A Triassic, Jurassic, and Cretaceous time scale, in Geochronology, Time Scales, and Global Stratigraphic Correlation, edited by W. A. Berggren, D. V. Kent, Aubry, M.-P., Hardenbol, J. SEPM Special Publication, 54, pp. 95-126, 1995.

Gradstein, F. M., J. G. Ogg, A. G. Smith, F. P. Agterberg, W. Bleeker, R. A. Cooper, V. Davydov, P. Gibbard, L. A. Hinnov, M. R. House, L. Lourens, H-P. Luterbacher, J. McArthur, M. J. Melchin, L. J. Robb, J. Shergold, M. Villneuve, B. R. Wardlaw, J. Ali, H. Brinkhuis, F. J. Hilgen, J. Hooker, R. J. Howarth, A. H. Knoll, J. Laskar, S. Monechi, J. Powell, K. A. Plumb, I. Raffi, U. Rohl, A. Sanfilippoo, B. Schmitz, N. J. Shackleton, G. A. Shields, H. Strauss, J. Van Dam, J. Veizer, T. H. Van Kolfschoten, and D. A. Wilson, Geological Time Scale 2004, Cambridge University Press, 384 pp., 2004.

Gvirtzman, G., T. Weissbrod, G. Baer, and G. J. Brenner, The age of the Aptian Stage and its magnetic events: new Ar-Ar ages and palaeomagnetic data from the Negev, Israel, Cretaceous Res., 17, 293-310, 1996.

Heirtzler, J. R., G. O. Dickson, E. M. Herron, W. C. I. Pitman, and X. LePichon, Marine anomalies: geomagnetic field reversals, and motions of the ocean floor and continents, J. Geophys. Res., 73, 2119-2136, 1968.

Helsley, C. E. and M. B. Steiner, Evidence for long intervals of normal polarity during the Cretaceous period, Earth Planet. Sci. lett., 5, 325332, 1969.

Kashiyama, Y., D. E. Fastovsky, S. Rutherford, J. King, and M. Montellano, Genesis of a locality of exceptional fossil preservation: paleoenvironments of Tepexi de Rodgríguez (mid-Cretaceous, Puebla, Mexico), Cretaceous Res., 24, 407-431, 2003.

Keating, B. and C. E. Helsley, Magnetostratigraphy of Cretaceous sediments from DSDP Site 369, edited by Y. Lancelot, E. Siebold et al.,
Init. Repts. DSDP, 41: Washington (U.S. Govt. Printing Office), 983 986, 1978a.

Keating, B. and C. E. Helsley, Magnetostratigraphy of Cretaceous age sediments from Sites 361, 363, 364, and 365, edited by H. M. Bolli, W. B. F. Ryan et al., Init. Reps. DSDP, 40: Washington (U.S. Govt. Printing Office), 459-467, 1978b.

Keating, B. and C. E. Helsley, Magnetostratigraphy of Cretaceous sediments from DSDP Site 386, edited by B. Tucholke, P. Vogt et al., Init. Reps. DSDP, 43: Washington (U.S. Govt. Printing Office), 781-784, 1979 .

Kirschvink, J. L., Least-squares lines and plane the analysis of paleomagnetic data, Geophys. J. Roy. Astron. Soc., 62, 699-718, 1980.

Lowrie, W., Identification of ferrimagnetic minerals in rock by coercivity and unblocking temperature properties, Geophys. Res. Lett., 17(2), 159$162,1990$.

McFadden, P. L. and M. W. McElhinny, Classification of the reversal test in palaeomagnetism, Geophys. J. Int., 103, 725-729, 1990.

Opdyke, N. D. and J. E. T. Channell, Magnetic Stratigraphy, 344 pp, Academic Press, San Diago California, USA, 1996.

Pantoja-Alor, J., Geología y paleoambientes de la Cantera Tlayua, Tepexi de Rodríguez, Estado de Puebla, Universidad Nacional Autonoma de Mexico, Inst. Geol. Rev., 9, 156-176, 1992.

Raff, A. D., Boundaries of an area of very long magnetic anomalies in north east Pacific, J. Geophys. Res., 71, 2631-2636, 1966.

Reynoso, V. H., Huehuecuetz palli mixtecus gen. et sp. nov: a basal squamate (Reptilia) from the Early Cretaceous of Tepexi de Rodriguez, Central Mexico, Philos. Trans. Roy. Soc. Lond. B, 353, 477-500, 1998.

Reynoso, V., H., An unusual aquatic Sphenodontian (Reptilia: Diapsida) from the Tlayua Formation (Albian), central México, J. Paleont., 74(1), 133-148, 2000

Reynoso, V. H. and G. Callison, A new scincomorph lizard from the Early Cretaceous of Puebla, Mexico, Zool. J. Linnean Soc., 130, 183-212, 2000 .

Seibertz, E. and B. Buitron, Investigaciones paleontologicas y su aplicacion bioestratigrafica de los Neohibolites de Tepexi de Rodriguez, Edo. de Puebla (Albiano, Cretacico medio, Mexico), El Cretacico de Mexico y America Central, resumenes, Act. Fac. Cien. Tierra Univ. Aut. Nuev. Leon Lin., 2, 121-124, 1987a.

Seibertz, E. and B. Buitron, Paleontología y estratigrafía de los Neohibolites del Albiano de Tepexi de Rodríguez, Edo. de Puebla (Cretacico Medio, Mexico), Rev. Soc. Mex. Paleontol., 1, 285-299, 1987 b.

Seibertz, E. and C. Spaeth, Cretaceous belemnites of Mexico III, The Albian Neo- and Mesohibolites of the "Mexican Solnhofen" Tepexi de Rodriguez (State of Puebla) and their biostratonomy (Lower Cretaceous), N. Jb. Geol. Paleontol. Abh., 255(1), 55-74, 2002.

Tarduno, J. A., Brief reversed polarity interval during the Cretaceous normal polarity superchron, Geology, 18(8), 683-686, 1990.

Tarduno, J. A., W. Lowrie, W. V. Sliter, T. J. Bralower, and F. Heller, Reversed Polarity characteristic magnetizations in the Albian Contessa section, Umbrian Apennines, Italy: Implications for the existence of a mid-Cretaceous Mixed Polarity Interval, J. Geophys. Res., 97, 241-271, 1992.

Urrutia-Fucugauchi J., Paleomagnetic study of the Cretaceous Morelos Formation, Guerrero State, southern Mexico, Tectonophysics, 147, 121$125,1988$.

Vandenberg, J., C. T. Klootwijk, and A. A. H. Wonders, Late Mesozoic and Cenozoic movements of the Italian Peninsula; further paleomagnetic data from the Umbrian Sequence, Geol. Soc. Am. Bull., 89, 133-150, 1978.

Wiedmann, J. and H. G. Owen, Late Albian ammonite biostratigraphy of the Kirchrode I borehole, Hannover, Germany, Palaegeogr., Palaeoclimatol., Palaeecol., 174, 161-180, 2001.

Zijderveld, J. D. A., AC demagnetization rocks: analyse of results, in Methods in paleomagnetism, edited by D. W. Collinson et al., Elsevier Sci. Publ., Amsterdam, pp. 254-286, 1967.

M. Benammi (e-mail: mouloud@igeofcu.unam.mx), J. AlvaradoOrtega, and J. Urrutia-Fucugauchi 